ROCZNIKI TEOLOGICZNE

Tom LXVI, zeszyt 2 - 2019

DOI: http://dx.doi.org/10.18290/rt.2019.66.2-2

\title{
KS. KRZYSZTOF GÓŹDŹ
}

\section{TEOLOGICZNE ROZUMIENIE MAŁŻEŃSTWA OSÓB OCHRZCZONYCH A NIEWIERZACCYCH}

\author{
THEOLOGICAL UNDERSTANDING OF MARRIAGE \\ AMONG THE BAPTIZED NON-BELIEVERS
}

\begin{abstract}
A b s t r a c t. Marriage is a divine plan, because it derives from God's power of creation and is expressed in two fundamental motives of creation: giving life and love (cf. Gen 2:7; $1: 27 ; 2: 18$ ). This is how the married couple builds communio personarum, an indivisible "one body", which on earth takes part in God's act of continua creatio. In other words, God created man in his image and likeness as "one body" of two persons, who actuate His love and His power to create (creation; offspring). And although the first Edenic marriage failed, in their offspring, the motif of the creative bond between the created and the love of God-creator perseveres. God's act of natural creation constitutes the deepest foundation of marriage, and as a sacrament, it constitutes a salvation act accomplished by Christ. Thus, Christ elevated the natural marriage to the dignity of a sacrament.

Contemporary Christians enter into marriage, even though there is a growing tendency among them to disbelieve in what the Church does (intention), or to declare a complete rejection of faith. We define these persons as baptized non-believers. However, through their unbelief they are not deprived of their link with the creative power of God and His love. The sacramental status of their marriage continues by virtue of their baptism and by the sacramental dispensation of grace ex opere operato. The personal faith of the married couple cannot waive the sacramental status of marriage, even though it can affect its fruitfulness. Also, the required nupturient intent - the intention to do what the Church does - which is the minimum necessary condition for entering into a sacramental union, is born of faith, and the lack of personal faith may thus affect the validity of the sacrament. Therefore, baptized non-believers
\end{abstract}

Ks. prof. dr hab. KRZYSZTOF GóźDŹ - Kierownik Katedry Historii Dogmatów i Teologii Historycznej Instytutu Teologii Dogmatycznej KUL; członek Komitetu Nauk Teologicznych PAN; konsultor Komisji Nauki Wiary przy KEP; członek Centralnej Komisji do Spraw Stopni i Tytułów; członek Międzynarodowej Komisji Teologicznej w Watykanie, redaktor polskiej edycji Opera Omnia Josepha Ratzingera; adres do korespondencji - e-mail: kgozdz@kul.pl 
who marry without personal faith and without the intention of doing what the Church does, do not conclude a purely natural marriage. "For the Church, between the two baptized, there is no natural marriage separate from the sacrament, but only a natural marriage elevated to the dignity of a sacrament." (International Theological Commission, Catholic Doctrine on the Sacrament of Marriage, p. 98). Thus the Church conditions the spiritual life of all Her members, unites them into one organic whole, leads them to fulfilment and personalization as much as possible, so that all Christians are one in Christ Jesus (cf. Gal 3:28).

Therefore, the baptized who are no longer believers can have a sacramental, inseparable marriage in the Catholic Church, which also makes amends for the shortcomings of their faith (Ecclesia suplet). Although the lack of living personal faith deprives marriage of its sacramental fruit, it does not exclude the couple from the Church - which they entered by virtue of baptism. Another reason for non-exclusion is the fact that marriage as such is a manifestation of God's will (cf. Gen 1:27; 2:24).

Key words: natural marriage; christian marriage; marriage of baptized and non-believers; faith and sacrament; sacramentality of marriage; faith and disbelief.

W dziejach ludzkości dokonują się głębokie zmiany w społecznej instytucji małżeństwa spowodowane krzyżowaniem się różnorodności kultur, religii, struktur społecznych i ekonomicznych (por. KDK 47), ale z drugiej strony zachowana zostaje chrześcijańska idea pojmowania małżeństwa jako wspólnoty życia i miłości ustanowionej przez Stwórcę. Małżeństwo chrześcijańskie jest rozumiane jako „dobrowolnie zawiązana wspólnota życia ochrzczonego mężczyzny z ochrzczoną kobietą, wspólnota pełna, wyłączna i osobowa, która odzwierciedla przymierze Chrystusa ze swym Kościołem i za pośrednictwem którego małżeństwo staje się skutecznym znakiem udzielania łaski uświęcającej" ${ }^{1}$. Małżeństwo dwojga ochrzczonych jest więc sakramentem, gdyż jest kontraktem (przymierzem) między kobietą a mężczyzną, będącym z woli Chrystusa skutecznym znakiem dobra nadprzyrodzonego udzielanego małżonkom przez Boga, a także znakiem miłości Chrystusa i Jego Kościoła (por. KKK 1604). Z kolei Kodeks Prawa Kanonicznego dodaje: „Małżeńskie przymierze, przez które mężczyzna i kobieta tworzą ze sobą wspólnotę całego życia, skierowaną ze swej natury do dobra małżonków oraz do zrodzenia i wychowania potomstwa, zostało między ochrzczonymi podniesione przez Chrystusa Pana do godności sakramentu" (kan. 1055 § 1).

Już w tych krótkich określeniach małżeństwa pojawiają się wielkie pytania: Jak wyjaśnić obraz małżeństwa w relacji miłości Chrystusa do Kościoła; Czy małżeństwo między ochrzczonym a nieochrzczonym jest sakramentem, czy nie? Czy do zawarcia małżeństwa ochrzczonych potrzebna jest wiara?

${ }^{1}$ G.L. MÜLLER, Dogmatyka katolicka, przekł. W. Szymona OP, Wydawnictwo WAM, Kraków 2015, s. 768. 


\section{ISTOTA MAŁŻEŃSTWA WEDŁUG BIBLII}

Małżeństwo wywodzi się z Bożego zamysłu stworzenia i wyraża się w dwóch ściśle związanych ze sobą podstawowych motywach: dawania życia i miłości, albo miłości stwórczej. Motywy te wystąpiły w stwórczym akcie Bożym: „Bóg ulepił człowieka z prochu ziemi i tchnął w jego nozdrza tchnienie życia (nefesz, Rdz 2,7). „Stworzył mężczyznę i niewiastę” ( $\operatorname{Rdz} 1,27)$, żeby się dopełniali, żeby żadne nie było samo (por. Rdz 2,18), lecz żeby tworzyli taką communio personarum (Jan Paweł II), która będzie stanowiła jedną, pełną istotę ludzką: „Dlatego mężczyzna opuszcza ojca swego i matkę swoją i łączą się z żoną tak ściśle, że stają się jednym ciałem” (Rdz 2,24). Naukę tę przyjął Chrystus jako objawioną: „Nie czytaliście, że Stwórca od początku stworzył ich jako mężczyznę i kobietę? Dlatego opuści człowiek ojca i matkę i złączy się ze swoją żoną, i będą oboje jednym ciałem. A tak już nie są dwoje, lecz jedno ciało. Co więc Bóg złączył, niech człowiek nie rozdziela" (Mt 19,4-6). Na tej podstawie Chrystus opiera nierozerwalność małżeństwa z wyjątkiem oddalenia żony kazirodczej (por. Mt 19,7-9)². „Jedno ciało" jest tak nierozerwalne, jak miłość i stworzenie (bytowanie), czyli małżeństwo przyjmuje na ziemi udział w Bożym akcie continua creatio. Powierzył mu to Bóg: „Bądźcie płodni i rozmnażajcie się, abyście zaludnili ziemię i uczynili ją sobie poddaną" (Rdz 1,28). A zatem Bóg nie stworzył człowieka pojedynczego, lecz ,jedno ciało” dwuosobowe, realizujące miłość i twórczość (stworzenie; potomstwo). W tym człowiek jest na obraz i podobieństwo Stwórcy (por. Rdz 1,26-27). Obraz oddaje ontologię, a podobieństwo - życie, działalność i moralność (św. Ireneusz z Lyonu) ${ }^{3}$. Wymiar działaniowo-moralny - „dobro i zło” (por. Rdz 2,15-17) wymagał przymierza między Bogiem a człowiekiem i między mężem a żoną, co miało rzutować na potomstwo i na społeczność. Zostało zawarte przymierze edeniczne czy Adamowe (por. Rdz 2,8nn). Jednak przymierze to pierwsza para ludzka zerwała (por. Rdz 3), tracąc tym samym prapierwotną sakramentalność małżeństwa, pozostało tylko małżeństwo „natury”, bez łaski nadprzyrodzonej.

Złamanie pierwszego małżeństwa - przymierza przeszło na potomstwo, ale wątek stwórczy związania stworzenia i miłości Bożej nie zaginął. Motyw małżeń-

\footnotetext{
${ }^{2}$ Innego zdania jest Międzynarodowa Komisja Teologiczna, Doktryna katolicka o sakramencie matżeństwa, w: Od wiary do teologii. Dokumenty Międzynarodowej Komisji Teologicznej 1969-1996, red. J. Królikowski, Wydawnictwo Księży Sercanów, Kraków 2000, s. 99: „Małżeństwo nie może zostać rozwiązane, nawet w przypadku cudzołóstwa”.

${ }^{3}$ IRENEUSZ z LyONU, Adv. haer. IV, 38.
} 
stwa edenicznego zajaśniał z całą mocą w mesjańskiej idei soteryjnej, według której Syn Boży przychodzi na świat, aby znów zaślubić człowieka i ludzkość z Bogiem. Oto uczniowie nie poszczą, dopóki pan młody jest z nimi (por. Mt 9,14-16; Mt 25,5-6), a gospodarz świata urządza ucztę weselną (por. Mt 22,123). To mesjańskie (uniwersalne) małżeństwo ludzkości z Synem Bożym ${ }^{4}$ wiąże się także z odrodzeniem się na sposób mesjański w każdym małżeństwie indywidualnym (por. J 2,1-12), a twórcza i zbawcza miłość między Chrystusem a Kościołem winna znajdować swoje odzwierciedlenie między małżonkami chrześci-

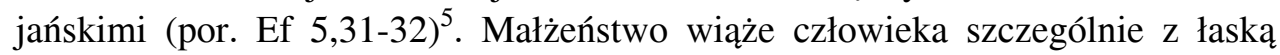
Chrystusową i z Kościołem. W konsekwencji małżeństwo (i rodzina) stało się rodzajem transformacji indywidualnej kreacji miłości w miłość społeczną, eklezjalną i soteryjną. A wreszcie małżeństwo i rodzina z niego wyrastająca okazały się tak istotne, że całe chrześcijaństwo, cała rzeczywistość religijna i życiowa zostały osadzone na kategoriach małżeńskich i rodzinnych: Bóg Ojciec, Syn Boży, Matka Boża, dziecko Boże, Rodzina Boża, wspólnota rodzinna, ojciec, matka, syn, córka, bracia, siostry itd. oraz wszelkie relacje między wszystkimi. Toteż kategoria małżeństwa jest święta, absolutna i nienaruszalna. Nawet nie wolno rezygnować $\mathrm{z}$ tejże terminologii.

\section{MAŁŻEŃSTWO OCHRZCZONYCH NIEWIERZĄCYCH}

Stoimy przed bardzo istotnym pytaniem dogmatycznym, prawnym i duszpasterskim, a mianowicie, czy małżeństwo jako obrzęd liturgiczny ma charakter sakramentalny, jeśli przystępują do niego osoby ochrzczone wprawdzie, ale niewierzące. Ogólnie rysują się dwie szkoły co do sytuacji, gdy jedna osoba jest ochrzczona, a druga nieochrzczona. Według jednych osoba ochrzczona otrzymuje sakrament, a osoba nieochrzczona nie otrzymuje sakramentu ${ }^{6}$. Natomiast według drugiej szkoły tenże związek obu osób (ochrzczonej z nieochrzczoną) nie jest sakramentalny ${ }^{7}$.

\footnotetext{
${ }^{4}$ Por. K. GóźDź, Świętojańskie zjednoczenie historii z Transcendencja w wydarzeniach Kany $i$ Golgoty, w: K. WIELICZKO (red.), Matka Odkupiciela, Lublin 2006, s. 37-46.

${ }^{5}$ Międzynarodowa Komisja TeOlogiczna, Doktryna katolicka o sakramencie matżeństwa, s. 94: „Małżeństwo chrześcijańskie jest uobecnieniem tajemnicy, jaka łączy Jezusa Chrystusa i Kościół. Analogia ta jest głębiej wyjaśniana przez interpretację teologiczną: najwyższa miłość i dar Pana aż do śmierci, jak również wierna i nieodwołalna więź Kościoła, Jego Oblubienicy, stają się wzorami i przykładami dla małżeństwa chrześcijańskiego”.

${ }^{6}$ Por. Z. JANCZEWSKI, Matżeństwo niesakramentalne chrześcijan, „Ius Matrimoniale” 12 [18] (2007), s. 38. Autor tego artykułu zalicza tu M. Rosseta, G. Perronego i in.

${ }^{7}$ Tamże. Do tej szkoły należą: H. Noldin, F. Bączkowicz, G. Dzierżon.
} 
W każdym razie rodzi się problem wspólny i ogólny: czy niewierzący, choć ochrzczeni, zawierają związek sakramentalny. Problem ten staje się dręczący coraz bardziej z tego powodu, że jest coraz więcej chrześcijan, którzy po chrzcie w dzieciństwie traca wiarę lub odrzucaja w ogóle wiarę w znaczeniu religijnym, a zachowują jedynie tradycyjne obrzędy zewnętrzne. Pytanie to zostało postawione już w roku 1977 za Pawła VI przez Międzynarodową Komisję Teologiczną ${ }^{8}$, a następnie przez V Zgromadzenie Synodu Biskupów w roku 1980 za papieża św. Jana Pawła II $^{9}$, przez Josepha Ratzingera jako kardynała w roku 1997 oraz jako papieża w roku $2005^{10}$, a ostatnio na Synodzie Biskupów z roku 2014 i 2015 za papieża Franciszka oraz przez samego papieża w roku $2016^{11}$.

Aby wejść w medias res zagadnienia, trzeba poddać analizie pojęcie wiary oraz sakramentu małżeństwa. Należy tu odróżnić sytuację dwojga ochrzczonych, którzy zawierają - według prawa kanonicznego - zawsze ważny związek sakramentalny (por. kan. $1055 \S 2$; DH 1800-1801). Nie ma tutaj mowy

\footnotetext{
${ }^{8}$ La doctrina católica sul sacramento del matrimonio, w: COMMISSIONE TEOLOGICA INTERNATionale, Documenti 1969-2004, Edizioni Studio Domenicano, Bologna 2010, s. 137-163.

${ }^{9}$ Por. posynodalną adhortację apostolską Familiaris consortio, $\mathrm{nr} 68$.

${ }^{10}$ W 1998 r. ówczesny prefekt Kongregacji Nauki Wiary, kard. Joseph Ratzinger, napisał wprowadzenie do książki pt. $O$ duszpasterstwie rozwiedzionych, którzy zawarli nowe zwiazki matżeńskie, opublikowanej przez Watykańską Księgarnię Wydawniczą i należącej do serii wydawanej przez tę Kongregację («Documenti i Studi», 17): O zastrzeżeniach dotyczacych nauki Kościoła na temat przyjmowania komunii św. przez wiernych rozwiedzionych, którzy zawarli nowe zwiazki matżeńskie, https://opoka.org.pl/biblioteka/W/WR/kongregacje/kdwiary/ratzinger _intro-roz1998.html (dostęp: 12.12.2018); Benedykt XVI, Incontro con il clero della diocesi di aosta. Discorso di sua santità Benedetto XVI Chiesa parrocchiale di Introd (Valle d'Aosta), 25 luglio 2005: https://w2.vatican.va/content/benedict-xvi/it/speeches/2005/july/documents/hf_ ben-xvi_spe_20050725_diocesi-aosta.html (dostęp: 12.12.2018).

${ }^{11}$ Papież FranciszeK, Amoris laetitia, 75. W przemówieniu do Roty Rzymskiej (22.01. 2016) Ojciec Święty powiedział: „Dobrze jest wyraźnie zaznaczyć, że jakość wiary nie jest zasadniczym warunkiem zgody małżeńskiej, która, według odwiecznej doktryny, może być niszczona tylko na poziomie naturalnym (por. KPK, kan. 1055, § 1 i $\S 2$ ). W istocie habitus fidei jest wszczepiany w chwili chrztu i dalej tajemniczo działa w duszy, również wówczas, kiedy wiara nie została rozwinięta i z psychologicznego punktu widzenia wydaje się nieobecna. Nierzadko narzeczeni, przynaglani do prawdziwego małżeństwa przez instinctus naturae, w chwili celebrowania mają ograniczoną świadomość pełni zamysłu Bożego i dopiero później, w życiu rodzinnym, odkrywają to wszystko, co Bóg, Stwórca i Odkupiciel, dla nich postanowił. Braki w formacji wiary, a także błąd co do jedności, nierozerwalności i sakramentalnej godności małżeństwa naruszają zgodę małżeńską tylko wówczas, jeżeli determinują wolę (por. KPK, kan. 1099). Właśnie dlatego błędy, które dotyczą sakramentalności małżeństwa, winny być rozważane bardzo uważnie" https://opoka.org.pl/biblioteka/W/WP/franciszek_i/przemowie nia/rota_22012016.html (dostęp: 12.12.18)].
} 
o wierze nupturientów. Jednak związek osoby ochrzczonej z nieochrzczoną - według niektórych kanonistów - nie jest małżeństwem sakramentalnym, lecz naturalnym ${ }^{12}$. Nas bardziej interesuje problem wiary i sakramentalności.

\section{a) Wiara i niewiara}

Wiara według teologii jest jedna z podstawowych tajemnic, a przez to jest wieloaspektowa i nie dająca się ując do głębi i bez reszty jednoznacznie. Ogólnie mówimy, że jest ona osobową odpowiedzią człowieka jako jednostki i jako społeczności eklezjalnej na zaproszenie wspólnoty z samoobjawiającym się i samoudzielającym się Bogiem (por. KKK 142-143). Jest więc z naszej strony całoosobowym przylgnięciem egzystencjalnym do Boga osobowego, a jednocześnie przylgnięciem do całej prawdy, którą Bóg objawił (por. KKK 150). Ujmując strukturalnie, wiara jest darem Boga i cnotą nadprzyrodzona (habitus), wlaną przez Niego (por. Mt 16,17) i zarazem z naszej strony aktem jak najbardziej ludzkim, osobowym, wolnym i rozumnym ${ }^{13}$. Rozum, wola i osoba współdziałają z łaską Bożą (por. KKK 155). Jednocześnie - o czym dziś się często zapomina - wiara nie jest bynajmniej rzeczywistością tylko indywidualną, wyizolowaną z życia zbiorowego, lecz jest z całą mocą także rzeczywistością społeczną, kościelną, jest „wiarą Kościoła” (por. KKK 166$169 ; 177-183)^{14}$. Ta wiara Kościoła ${ }^{15}$ ma charakter macierzysty, źródłorodny dla wiary indywidualnej, którą karmi, prowadzi, podtrzymuje, wzmacnia i dopełnia według zasady nie tylko jurysdykcyjnej: Ecclesia supplet fidem. Kościół jest w pewnym sensie wiarą zobiektywizowaną, uspołecznioną, uosobioną społecznie. Kościół na całym świecie - według ostatniego nakazu Chry-

\footnotetext{
12 Por. Z. JANCZEWSKI, Matżeństwo niesakramentalne chrześcijan, s. 40, 48.

${ }^{13}$ Por. K. GóźDŹ, Realność i racjonalność wiary, w: TENŻE, Logos i Miłość. Teologia Josepha Ratzingera-Benedykta XVI, Wydawnictwo KUL, Lublin 2018, s. 93-103.

14 Por. J. RATZINGER, Taufe und Formulierung des Glaubens, „Ephemerides Theologice Lovaniensis” 49(1973), s. 76-86; Cz.S. BARTNIK, Wiara Kościoła, „Collectanea Theologica” 51(1989), nr 6, s. 107-114; J. RATZINGER, Eklezjalna postać wiary, w: TENŻE, Opera Omnia, t. IV: Wprowadzenie do chrześcijaństwa. Wyznanie - Chrzest - Naśladowanie, przekł. R. Biel, M. Górecka, red. K. Góźdź, M. Górecka, Wydawnictwo KUL, Lublin 2017, s. 80-92; TENŻE, Opera Omnia, t. IX/1: Wiara w Piśmie i Tradycji. Teologiczna nauka o zasadach, przekł. J. Merecki SDS, red. K. Góźdź, M. Górecka, Wydawnictwo KUL, Lublin 2018, s. 39-345; TENŻE, t. IX/2: Kościót jako miejsce przepowiadania, s. 783-793; J. KRÓLIKOWSKI, Credo - Credimus. Wymiary przedmiotowe aktu wiary, Wydawnictwo Naukowe UPJPII, Kraków 2018, s. 21-61; 188-220.

15 Por. L. DALhaI, Fede e sacramenti, „Folia Athanasiana” 17(2015), s. 77 (Nyiregyháza, Węgry): „La fede della Chiesa precede la fede della credente e ogni sacramento, è un atto, una professione di fede ecclesiale”. Na temat „forma ecclesiale della fede” por.: Papież FrANCISZEK, Encyklika Lumen fidei, nr 39.
} 
stusa - będzie zbudowany na wierze i chrzcie: „Idźcie na cały świat i głoście Ewangelię wszelkiemu stworzeniu! Kto uwierzy i przyjmie chrzest, będzie zbawiony; a kto nie uwierzy, ten się potępi" (Mk 16,15-16). Wiara i chrzest czynią Kościół.

Taka jest wiara w ujęciu pełnym teologicznie, idealnym i docelowym, ale praktycznie dużo trudności nastręcza już sama terminologia biblijna. Na przykład w przywileju Pawłowym (por. 1 Kor 7,12-15), według którego strona chrześcijańska w małżeństwie mogła (choć nie musiała) porzucić stronę niechrześcijańską, różnie przekładano te strony z greki pistos i apistos: wierny i niewierny, chrześcijańska i niechrześcijańska, ochrzczona i nieochrzczona, wierząca w Boga i ateistyczna, chrześcijańska i pogańska (choć pogańska mogła być też religijna). Terminy i pojęcia te są nieostre.

Ta sama trudność dotyczy i dziś określenia „niewierzący” w ramach fides quae. Przede wszystkim trzeba pamiętać, że „niewierzący” nie musi oznaczać „ateista”. Najczęściej „niewierzący” jest określeniem potocznym i nieprecyzyjnym. Idealna wiara jest pojęciem daru obecności i realności Rzeczywistości Bożej w całej osobie ludzkiej, ale biorąc analitycznie i praktycznie, to w wierze mamy trzy obszary: umysłowy (noetyczny), wolitywno-emocjonalny i praktyczno-aktywny. Często występuje prymat albo nawet i wyłączność jednego obszaru. U ludzi bardzo żywych intelektualnie wiara jawi się często wyraźnie tylko w umyśle w postaci jakiegoś zestawu prawd czy twierdzeń, przy czym w stosunku do credo to często $\mathrm{w}$ jedne prawdy wierzą, a w inne nie wierzą. Intelektualiści bardzo lubią sobie dobierać nawet dogmaty, a wiele innych odrzucają, np. w Bóstwo Chrystusa, w nieśmiertelność. I nie maja żadnej emocji religijnej, ani nie praktykują. Natomiast inni żyją mocno światem religijnym, ale często tylko emocjonalnie, bez odpowiedniego zestawu prawd i pojęć. Wystarczy mocniejszy konflikt z duchownym, już porzuca wszystko i „nie wierzy”. W sytuacji wielkiego zakochania często sfera noetyczna staje się tak słaba, że przyjmuje się postawę odmienną od drugiej ukochanej osoby, choć trzeba pamiętać, że bez emocji byłoby dużo mniej i małżeństw religijnych. I wreszcie bywa też prymat obszaru działaniowego i praktycznego tak silny, że nie wiadomo, w co dokładnie dana osoba wierzy, co przeżywa w głębi duszy, bo staje się tylko wytworem i cząstką środowiska lub jakby robotem religijnym, choć może być to jakieś „,pisanie” ikony Chrystusa samym działaniem i praca. W każdym razie żadna redukcja wiary nie czyni człowieka „niewierzącym” czy ateistą, choć wiara katolicka winna się 
rozwijać we wszystkich trzech wymiarach osoby ${ }^{16}$. Niemniej nie wolno żądać od nupturientów tylko takiej wiary pleromicznej, bo musiałaby nastąpić wielka redukcja małżeństw sakramentalnych.

Poza tym mamy też poważne problemy $\mathrm{z}$ właściwym rozpoznaniem fides qua. Otóż wiara jest ,żywym” procesem komunii osoby ludzkiej z Osobami Bożymi, a więc ma swoją historię, etapy rozwojowe, fluktację, różną intensywność i różne stopnie rozpoznawalności. Jest bowiem również w pewnym sensie misterium, zarówno w postaci habitus, jak i aktu. Wiara jest w pewnym zakresie explicita, ale także zakryta lub implicita. Jest ona zwyczajna, codzienna, pospolita, ale i jakaś graniczna, głęboka, jakby niespodziewana. Jest wiara refleksyjna, ale i niepodpadająca pod autorefleksję. Dziś często wiarę umieszczamy na ekranie samej świadomości, tymczasem jest i podświadoma ${ }^{17}$. Może być, że nawet w autorefleksji człowiek właściwie nie wie, czy wierzy, czy nie wierzy: „A przecież człowiek nie wie, czy jest miłości czy nienawiści godzien” (Koh 9,1 - Wulgata). „Każdy człowiek pozostaje dla siebie nierozwiązanym, niejasno postrzeganym problemem" (KDK 21). Wreszcie u wielu chrześcijan stan wiary łączy się z moralnością, a stan niewiary z niemoralnością i głęboka niemoralność zazwyczaj zakrywa świadomość wiary.

W rezultacie misterium wiary każdy człowiek, każdy teolog i cały Kościół winien rozpoznawać, zgłębiać całą swoją osobą, wprowadzać w całe życie i obejmować nią nie tylko siebie, ale i całą rzeczywistość: „Wiemy przecież, że całe stworzenie aż dotąd jęczy i wzdycha w bólach rodzenia" (Rz 8,22 ; por. Rz 8,18-25).

\section{b) Wiara i sakrament}

Według teologii „chrzest jest sakramentem wiary” (KKK 1253). Znaczy to, że chrzest mógł zaistnieć dzięki wierze, danej od Boga i że następnie rolę daru wiary przejmuje Kościół jako sakrament, jako Grundsakrament. Sakrament chrztu czyni człowieka „nowym stworzeniem”, oczyszcza z wszelkich grzechów, czyni przybranym dzieckiem Bożym i Świątynią Ducha Świętego, wszczepia w Kościół, daje łaskę uświęcającą i daje cnoty teologalne: wiarę w Boga, nadzieję i miłość Boga (por. KKK 1265-1266). W naszym temacie ważna jest szczególnie wiara wlana już w chrzcie niemowlęcia: „Wiara jest

\footnotetext{
${ }^{16}$ Por. Cz.S. BARTNIK, Personalizm, Wydawnictwo KUL, Lublin 2013, s. 165-344; TENŻE, „Osoba” w filozofii i teologii, „Standruk”, Lublin 2017, s. 7-31.

${ }^{17}$ Przykładem może być takie często spotykane wydarzenie: Żołnierz, który głosił, że jest niewierzący, i wyśmiewał Chrystusa i Matkę Bożą, gdy zostaje ciężko ranny, wzywa Ich dramatycznie na pomoc.
} 
darem Bożym, cnotą nadprzyrodzoną, wlaną przez Niego" (KKK 153). Ale jest nie tylko wiara jednostki, bowiem jest także wiara Kościoła: „Kościół jest tym, który wierzy, i w ten sposób prowadzi, karmi i podtrzymuje naszą wiarę" (KKK 168). Wiara Kościoła poprzedza zatem wiarę wierzącego.

Nasuwają się tu dwa ważne pytania: 1) Jaką wiarę zakładają sakramenty? i 2) Co niszczy brak wiary?

Według Vaticanum II ,sakramenty bowiem nie tylko zakładają wiarę, lecz za pomocą słów i rzeczy ją podtrzymują, umacniają i wyrażają" (KL 59). Otóż wydaje się, że Kościół zakłada swoją wiarę eklezjalną w postaci przyjęcia Bożej ekonomii zbawienia przez życie i Ewangelię Syna Bożego oraz inspirację Ducha Świętego, a poszczególni wierni winni poprzedzać przyjmowanie sakramentów przez osobistą konkretyzację i personalizację wiary Kościoła $^{18}$. Każdy sakrament jest bowiem wyznawaniem wiary eklezjalnej. Jeśli chodzi o chrzest dzieci przed używaniem rozumu, to wystarczy wiara rodziców lub Kościoła, choć w Kościołach prawosławnych niemowlętom udziela się nie tylko chrztu, ale jednocześnie bierzmowania i Komunii świętej. Kościoły te bowiem nie łączą ściśle wiary ze świadomością i rozumieniem tajemnicy.

Co do drugiego pytania jest problem, co niweczy brak wiary, niewiara czy grzech śmiertelny? Niestety kwestie te nie są dostatecznie opracowane. Otóż przyjmuje się, że co do chrztu to grzech śmiertelny niweczy łaskę uświęcającą, ale pozostawia charakter sakramentalny (duchowe znamię, por. KKK 1272); a co z innymi owocami chrztu, jak dziecięctwo Boże czy uczestnictwo w naturze Bożej, no i co z wiarą wlaną? Są różne teorie na ten temat. A poza tym są pytania, co niweczy ciężki grzech przeciw wierze i czy niweczy cokolwiek niewiara niezawiniona (por. KK 16), czy z „brakiem wiary” zniweczonej przez lata przez ateistyczne społeczeństwo, państwo, czy zamknięte środowisko (por. KK 16).

Ani wiary, ani tym bardziej sakramentu nie wolno redukować tylko do świadomości religijnej, do bytu subiektywnego, co jest pokusą w mentalności nowoczesnej. Można powiedzieć, że poza Kościołem katolickim spotykamy pewne przeciwieństwo. Z jednej strony wspólnoty reformacyjne mają tendencję sprowadzania wiary do ufności słowu Bożemu, a łaski sakramentalnej do

\footnotetext{
18 Trafnie ujmuje to K.H. Menke, Sakramentalität. Wesen und Wunde des Katholizismus, Verlag Friedrich Pustet, Regensburg 2012², s. 129: „Als Sakrament ist die Kirche insgesamt, aber auch jedes ihrer Glieder Subjekt des Heilsgeschichte. [...] Also wird die Kirche in jeder einzelnen Eucharistiefeier erneut das, was sie nur von Christus her ist, sein Sakrament in Raum und Zeit".
} 
bezontycznej przychylności Boga. W każdym razie prymat ma czysto podmiotowa, subiektywna wiara, stąd m.in. ciężko chorzy umysłowo byliby pozbawieni i wiary, i sakramentu. Z drugiej zaś strony liczne Kościoły prawosławne widzą w sakramencie i wierze dar Boży ontyczny, realny, obiektywny i determinujący człowieka sakramentalnie, przebóstwiający go bez względu na jego stan subiektywny, np. niektóre wierzą, że Komunia święta gładzi grzechy ciężkie bez spowiedzi, w tym także grzechy niewiary. Natomiast według teologii katolickiej i wiara, i sakrament są ujmowane w paradygmacie chalcedońskim ${ }^{19}$, gdzie jest ścisłe zespolenie rzeczywistości Bożej z ludzką, elementu ontycznego, obiektywnego z subiektywnym, gdzie następuje eschatologiczne uczłowieczenie Boga i jednocześnie przebóstwienie człowieka, w całym jego bycie osobowym, nie tylko na płaszczyźnie świadomościowej, ale także na płaszczyźnie wolitywnej i prakseologicznej, czyli w całości przedmiotowo-podmiotowej. W rezultacie jeszcze raz wracamy do tej niezwykłej prawdy, że Kościól, do którego wprowadza chrzest, nie jest tylko jakąś zbiorowością izolowanych jednostek, lecz warunkuje życie duchowe tych wszystkich osób, wiąże w organiczną całość, daje im spełnienie i jak najdoskonalej personalizuje tak, że św. Paweł mógł napisać: „Wszyscy jesteście kimś jednym w Chrystusie Jezusie" (Ga 3,28). Św. Augustyn mógł nazwać Kościół osobą $^{20}$, a Pius XII uznał - za Leonem XII - że Duch Święty jest Duszą Kościoła $^{21}$. A zatem wiara i chrzest określają bardzo istotnie naszą egzystencję chrześcijańską i mają także misteryjne powiązania z innymi strukturami Kościoła.

\section{c) Podniesienie małżeństwa naturalnego do godności sakramentu}

Małżeństwo określamy jako „przymierze, przez które mężczyzna i kobieta tworzą ze sobą wspólnotę całego życia (communio personarum ${ }^{22}$, św. Jan Paweł II), skierowaną ze swej natury na dobro małżonków oraz zrodzenia

19 Por. K. GóźDŹ, Die personalistische Ergänzung des Chalkedonischen Dogmas, w: Ch. SCHALler i in. (red.), Mittler und Befreier. Die christliche Dimension der Theologie, Herder, Freiburg i.Br. 2008, s. 94-109.

${ }^{20}$ Epistula 140,18 PL 33, 545; Enarr. in Ps 142,3 PL 37,1845-1846.

${ }^{21}$ Encyklika Mystici Corporis, 45: „Tę właśnie obecność Ducha Jezusa Chrystusa nasz poprzednik Leon XIII, mądrością nader wsławiony, w encyklice Divinum illud zwięźle a dobitnie określił, mówiąc: «Niech wystarczy to powiedzieć, że gdy Chrystus jest Gtowa Kościoła, to Duch Św. jest Jego duszq»".

22 Por. K. WojtyŁA, Rodzina jako „communio personarum”, „Ateneum Kapłańskie” 66(1974), t. 83, z. 1, s. 17-31; TENŻE, Rodzicielstwo a „communio personarum”, „Ateneum Kapłańskie" 67(1975), t. 84, z. 3, s. 347-361; JAN PAWEE II, Familiaris consortio, nr 21. 
i wychowania potomstwa" (KKK 1601; por. KPK kan. 1055). Jego twórcą jest Bóg, który stworzył człowieka - mężczyznę i kobietę - (por. Rdz 1,27) $\mathrm{w}$ łonie świata, powierzając im udział $\mathrm{w}$ procesie stwarzania, kontynuacji rodzaju ludzkiego i znaku miłości Bożej (por. KDK 48). Jezus Chrystus podniósł je do godności sakramentu (por. Ef 5,31-32). Istotą aktu zawarcia małżeństwa jest osobowe wyrażenie woli i zgody na sposób trwałego przymierza, przez które małżonkowie wzajemnie się sobie oddają i przyjmują (por. KDK 48; KPK 1057 § 2). Tak więc najgłębszą podstawą małżeństwa jest naturalny akt stwórczy Boga, a jego sakramentalność jest aktem zbawczym, dokonanym przez Chrystusa. Dlatego można powiedzieć skrótowo, że dla małżeństwa naturalnego, ustanowionego przez Stwórcę, wystarczy bycie wolnymi i zdatnymi do tego mężczyzny i kobiety, a dla małżeństwa sakramentalnego w pełnym znaczeniu trzeba jeszcze wiary i chrztu.

A zatem w dobie subiektywności sacrum, a zwłaszcza laicyzacji, stawia się coraz częściej i mocniej pytania, czy może być małżeństwo sakramentalne bez wiary w Chrystusa lub w ogóle bez Boga, czy nie powinno zostać sprowadzone do samej podmiotowej wiary, a nawet, czy nie wyłączyć małżeństwa z liczby sakramentów, traktując je jako kontrakt naturalny i świecki, jak robią to niektóre Kościoły niekatolickie oraz niemal wszystkie wspólnoty reformacyjne.

Spróbujmy zatem sprecyzować główny problem, analizując zwłaszcza terminologię co do wiary qua: czy chodzi o żywotność i intensywność wiary lub o jej wcielenie w życie? Czy też o całkowity brak wiary? Co do wiary quae: czy chodzi o brak wiary w ogóle w Boga, czy w Bóstwo Jezusa, w Kościół, czy wreszcie tylko o brak wiary lub intencji uznania sakramentalnego charakteru małżeństwa? Następnie należy bardziej konkretnie ustalić czas niewiary: czy chrzest miał miejsce przed dojściem do pełnego używania rozumu, czy potem w okresie zawierania ślubu, czy też dopiero po zawarciu małżeństwa. Myślę jednak, że można będzie ująć samą istotę problemu w jedno pytanie teoretyczne, a mianowicie: czy niewierzący w znaczeniu potocznym, ale już dawniej ochrzczeni, mogą mieć małżeństwo sakramentalne i nierozerwalne w Kościele katolickim?

Każdy sakrament, stanowiący religijne misterium, zakłada wiarę (por. KL 59). Toteż i sam Kościół jako Grundsakrament i jako „Osoba społeczna” wyrósł z wiary w orędzie Jezusa Chrystusa. Jest więc Kościół wiary i wiara Kościoła. Jeśli zatem nupturieci dokonali zgody małżeńskiej, która jest istotą małżeństwa in facie Ecclesiae w eklezjalnej celebracji rytu, to tym samym 
wyrazili, choćby implicite, że robią to, czego uczy Kościół ${ }^{23}$, a nie wykluczaja tego wewnętrznie, czynią to w wierze Kościoła, który też zaradza niedostatkom ich wiary. Zasada Ecclesia supplet odnosi się nie tylko do samej jurysdykcji. Życie ochrzczonego w niewierze, w stanie niewiary, nie jest nielogicznością sakramentalną, bowiem i wierzący może mieć grzechy przeciwko wierze, jak i sa grzechy przeciw chrztowi, kapłaństwu i bierzmowaniu, które przez to nie są bynajmniej niwelowane. Według nauki katolickiej sakramenty, a także wiara, nie są tylko tworami myślnymi, lecz również realnościami łaski Bożej obiektywnej.

Następnie wiara, konieczna do sakramentu małżeństwa, wywodzi się właśnie z chrztu, który jest bramą do ekonomii zbawienia. Chrzest jest szczególną obecnością Bożą w człowieku i mocą. Bóg nie tylko czyni ochrzczonego nowym stworzeniem (por. 2 Kor 5,17; Ga 6,15), ale także obdarza go realnymi uzdolnieniami do wiary, właściwie jest to ziarno wiary, a także ziarno nadziei, przez którą ochrzczony ma zaczątek miłości Boga i człowieka jako podstawowej treści istnienia (por. 1 Kor 13,13). Toteż na mocy chrztu już niemowlę może przyjąć bierzmowanie, Eucharystię, a nawet i święcenia (np. u Koptów). Tym samym rysuje się tu szczególna antropologia, także sakramentowa. Okazuje się, że już embrion ludzki ma duszę i jest osobą (św. Jan Paweł II $)^{24}$. I niemowlę przez dary sakramentalne nie jest zniewolone, tyle że wraz z rozwojem coraz bardziej się personalizuje i deklaruje. Niemniej płynie $\mathrm{z}$ tego nauka, że wiara nadprzyrodzona nie może być sprowadzana do samej świadomości czy naturalnej decyzji. Prawdziwą wiarę chrześcijańską można mieć i bez świadomości. Moga ją zatem mieć i ludzie bardzo ciężko chorzy psychicznie, choć sami mogą o tym nie wiedzieć. Chrzest dzieci pokazuje, że w ciągu lat wiara rozmaicie się krystalizuje, ale w istocie zawsze jest

\footnotetext{
${ }^{23}$ Międzynarodowa Komisja TeOlogicZna, Doktryna katolicka o sakramencie matżeństwa, s. 95: „Wymagana intencja - czyli intencja czynienia tego, co czyni Chrystus i Kościół - jest minimalnym koniecznym warunkiem do tego, aby naprawdę miał miejsce ludzki akt zaangażowania na poziomie sakramentalnym. Oczywiście, nie należy mieszać problemu intencji z problemem osobistej wiary zawierających małżeństwo, ale jest rzeczą równie niemożliwą całkowicie je oddzielać. Ostatecznie prawdziwa intencja rodzi się z wiary i jest nią karmiona. [...] Osobista wiara zawierających małżeństwo nie konstytuuje, jak to zostało podkreślone, sakramentalności małżeństwa, ale brak osobistej wiary wystawia na ryzyko ważność sakramentu”. W duszpasterskiej trosce dołącza się tu ważne zdanie: „sakrament małżeństwa zakłada wiarę i jej wymaga" (Ordo celebrandi matrimonium. Praenotanda, 7).

24 JAN PAWE€ II, Encyklika Evangelium vitae, 60; por. KongregaCJa NAUKI WIARY, Instrukcja o szacunku dla rodzącego się życia ludzkiego i o godności jego przekazywania Donum vitae, I,1.
} 
ta sama i nie może być rozmywana do końca, jak sam charakter, znamię chrztu (sfragis, singnaculum, signum indelebile).

Teologia łacińska zatem zmierza ku temu, że w małżeństwie klasycznym i integralnym obie strony udzielają sobie sakramentu, ale w łonie Kościoła, który kładzie na to pieczęć. Natomiast w teologii wschodniej to Kościół udziela sakramentu małżeństwa. Według naszej teologii znakiem sakramentalnym jest odpowiednie wyrażenie zgody i miłości małżeńskiej, a znak ten w Kościele oznacza włączenie naturalnego małżeństwa w ekonomię zbawienia, w miłość Bożą, w komunię z Kościołem, kontynuację i uświęcenie życia oraz tworzenie „Kościoła domowego”, Kościoła rodziny (por. Dz 18,8; Rz 8,4; KK 11; KKK 1655-1657). Brak żywej wiary pozbawia małżeństwo owoców sakramentalnych, ale nie wyklucza - z racji chrztu - z Kościoła, jak i z tej racji, że małżeństwo w ogóle jest z woli Bożej (por. Rdz 1,27; 2,24) i jest zawsze poddane szczególnej Opatrzności, małżonkowie mają liczne dary naturalne (por. Dz 14,17) osobiste i rodzinne oraz różne łaski uczynkowe i inspiracje do nawrócenia. Trzeba zauważyć, że przy niewierze niezawinionej łaski zbawcze może przynosić szukanie Boga „po omacku” i wysoka moralność (por. KK 16).

Co więcej, małżeństwo ważne - jak już zostało wspomniane - otrzymuje niezmywalny charakter sakramentalny, dzięki któremu ma wyższą zdolność przyjęcia łaski nawrócenia. I gdyby tacy małżonkowie nawrócili się, to ceremonii ślubu się nie powtarza i cały sakrament ożywa (vivificatio), a ślub ochrzczonych bez kontaktu z Kościołem, np. w sytuacji surowych prześladowań, może być potem tylko pobłogosławiony przez kapłana. W każdym razie, kto porzuca związek małżeński z własnej winy, czy to naturalny, czy z racji niewiary, grzeszy przeciwko Bogu Ojcu i Chrystusowi, i wejście w nowy związek jest cudzołóstwem (por. Mt 19,5; 1 Kor 6,16; Ef 5,31), choćby osoby te nie zdawały sobie z tego sprawy. Często bowiem ludzie zrywający naturalne małżeństwo świeckie sądzą, że ewentualna wina dotyczy tylko małżeństwa kościelnego. Papież Celestyn III (1191-1198) uważał, że odejście od wiary, nawet w małżeństwie chrześcijańskim, rozwiązuje legalnie związek. Ale ta opinia została przez Kościół odrzucona (DH 769). Było to bowiem niesłuszne rozciągnięcie przywileju Pawłowego.

$\mathrm{Na}$ koniec ważny jest także argument pastoralny. Bowiem odrzucenie sakramentalności małżeństwa ochrzczonych a niewierzących, choćby tylko „uśpionego religijnie”, prowadzi niewątpliwie do ciężkiego osłabienia instytucji małżeństwa, a także rodziny w ogóle, i w epoce sekularyzmu, ateizmu i głębokiego kryzysu moralnego spowoduje jeszcze większą lawinę rozpadu małżeństw ludzi wierzących i w ogóle rezygnacji ze ślubu kościelnego, a co 
za tym idzie powszechnego rozkładu rodzin. Każdy bowiem człowiek złej woli mógłby powołać się w rozprawie o rozwiązanie jego związku kościelnego na swój brak wiary, a brak wiary czy niewiara nie dadzą się dowolnie sprawdzić. Dlatego to i KPK nie umieszcza braku wiary lub niewiary wśród przeszkód zrywających małżeństwo.

\section{BIBLIOGRAFIA}

Augustyn, Epistula 140,18 PL 33, 545; Enarr. in Ps 142,3 PL 37,1845-1846.

BARTNIK Cz.S., Personalizm, Wydawnictwo KUL, Lublin 2013.

BARTNIK Cz.S., Wiara Kościoła, „Collectanea Theologica” 51(1989), nr 6, s. 107-114.

BARTNIK Cz.S. „Osoba” w filozofii i teologii, „Standruk”, Lublin 2017.

BENEDYKT XVI, Incontro con il clero della diocesi di aosta. Discorso di sua santità Benedetto XVI Chiesa parrocchiale di Introd (Valle d'Aosta), 25 luglio 2005: https://w2.vatican.va/content/ benedict-xvi/it/speeches/2005/july/documents/hf_ben-xvi_spe_20050725_diocesi-ao sta.html (dostęp: 12.12.2018).

DalHai L., Fede e sacramenti, „Folia Athanasiana” 17(2015), s. 67-91.

GóźDŹ K., Die personalistische Ergänzung des Chalkedonischen Dogmas, w: Ch. ScHALlER $\mathrm{i}$ in. (red.), Mittler und Befreier. Die christliche Dimension der Theologie, Herder, Freiburg i.Br. 2008, s. 94-109.

GóźDŹ K., Realność i racjonalność wiary, w: TENŻE, Logos i Miłość. Teologia Josepha Ratzingera-Benedykta XVI, Wydawnictwo KUL, Lublin 2018, s. 93-103.

GóźDŹ K., Świętojańskie zjednoczenie historii z Transcendencją w wydarzeniach Kany i Golgoty, w: K. WIELICZKO (red.), Matka Odkupiciela, Lublin 2006, s. 37-46.

IRENEUSZ Z LYONU, Adv. haer. IV, 38.

JAN PAWEE II, Adhortacja apostolska Familiaris consortio, Watykan 1981.

JAN PAWE€ II, Encyklika Evangelium vitae, Watykan 1995.

JANCZEWSKI Z., Małżeństwo niesakramentalne chrześcijan, „Ius Matrimoniale” 12 [18] (2007), s. $35-49$.

KONGREGACJA NAUKI WIARY, Instrukcja o szacunku dla rodzącego się życia ludzkiego i o godności jego przekazywania Donum vitae, Watykan 1987.

KRÓLIKOWSKI J., Credo - Credimus. Wymiary przedmiotowe aktu wiary, Wydawnictwo Naukowe UPJPII, Kraków 2018.

La doctrina católica sul sacramento del matrimonio, w: COMMISSIONE TEOLOGICA INTERNATIONALE, Documenti 1969-2004, Edizioni Studio Domenicano, Bologna 2010, s. 137-163.

MENKE K.H., Sakramentalität. Wesen und Wunde des Katholizismus, Werlag Friedrich Pustet, Regensburg $2012^{2}$.

Międzynarodowa KomisJa TeOlogiczna, Doktryna katolicka o sakramencie małżeństwa, w: Od wiary do teologii. Dokumenty Międzynarodowej Komisji Teologicznej 1969-1996, red. J. Królikowski, Wydawnictwo Księży Sercanów, Kraków 2000, s. 89-110.

MÜLLER G.L., Dogmatyka katolicka, przekł. W. Szymona OP, Wydawnictwo WAM, Kraków 2015.

PAPIEŻ FranCISZEK, Amoris laetitia, 75.

PAPIEŻ FrANCISZEK, Przemówienie do Roty Rzymskiej (22.01.2016) https://opoka.org.pl/bib lioteka/W/WP/franciszek_i/przemowienia/rota_22012016.html (dostęp: 12.12.2018). 
PIUS XII, Encyklika Mystici Corporis, Watykan 1943.

RATZINGER J., Eklezjalna postać wiary, w: TENŻE, Opera Omnia, t. IV: Wprowadzenie do chrześcijaństwa. Wyznanie - Chrzest - Naśladowanie, przekł. R. Biel, M. Górecka, red. K. Góźdź, M. Górecka, Wydawnictwo KUL, Lublin 2017, s. 80-92.

RATZINGER J., Kościół jako miejsce przepowiadania, w: TENŻE, Opera Omnia, t. IX/2: Wiara w Piśmie i Tradycji. Teologiczna nauka o zasadach, przekł. J. Merecki SDS, red. K. Góźdź, M. Górecka, Wydawnictwo KUL, Lublin 2018, s. 783-793.

RATZINGER J., O duszpasterstwie rozwiedzionych, którzy zawarli nowe związki małżeńskie, w: Kongregacja Nauki Wiary, Documenti i Studi, 17: O zastrzeżeniach dotyczących nauki Kościoła na temat przyjmowania komunii św. przez wiernych rozwiedzionych, którzy zawarli nowe związki małżeńskie, https://opoka.org.pl/biblioteka/W/WR/kongregacje/kdwia ry/ratzinger_intro-roz1998.html (dostęp: 12.12.2018).

RAtZINGer J., Opera Omnia, t. IX/1: Wiara w Piśmie i Tradycji. Teologiczna nauka o zasadach, przekł. J. Merecki SDS, red. K. Góźdź, M. Górecka, Wydawnictwo KUL, Lublin 2018, s. 39-345.

RAtZINGER J., Taufe und Formulierung des Glaubens, „Ephemerides theologice Lovaniensis” 49(1973), s. 76-86.

RYCHLICKI Cz., Sakramentalny charakter przymierza małżeńskiego. Studium teologicznodogmatyczne, Płocki Instytut Wydawniczy, Płock 1997.

WoJTYŁA K., Rodzicielstwo a „communio personarum”, „Ateneum Kapłańskie” 67(1975), t. 84, z. 1, s. 17-31.

WoJTYŁA K., Rodzina jako „communio personarum”. Próba interpretacji teologicznej, „Ateneum Kapłańskie” 66(1974), t. 83, z. 3, s. 347-361.

\title{
TEOLOGICZNE ROZUMIENIE MAŁŻEŃSTWA \\ OSÓB OCHRZCZONYCH A NIEWIERZĄCYCH
}

\author{
S t r e s z c z e n i e
}

Małżeństwo jest z ustanowienia Bożego, gdyż wywodzi się z Bożego zamysłu stworzenia i wyraża się w dwóch podstawowych motywach stworzenia: dawania życia i miłości (por. Rdz $2,7 ; 1,27 ; 2,18)$, by $w$ ten sposób tworzyli communio personarum - nierozerwalne ,,jedno ciało", które przyjmuje na ziemi udział w Bożym akcie continua creatio. Bóg zatem stworzył człowieka na swój obraz i podobieństwo jako ,jedno ciało" dwuosobowe, realizujące Jego miłość i twórczość (stworzenie; potomstwo). I choć załamało się pierwsze małżeństwo edeniczne, to jednak w ich potomstwie wątek stwórczy związania stworzenia i miłości Bożej nie zaginął. Tak więc najgłębszą podstawą małżeństwa jest naturalny akt stwórczy Boga, a jego sakramentalność jest aktem zbawczym, dokonanym przez Chrystusa. Tak Chrystus podniósł małżeństwo naturalne do godności sakramentu.

Dziś chrześcijanie zawierają związki małżeńskie, w których coraz częściej pojawiają się przypadki, że brak im wiary w to, co czyni Kościół (intencja), albo wprost odrzucają wiarę. Określamy ich jako osoby ochrzczone a niewierzące. Przez swoją niewiarę nie tracą jednak wątku stwórczego i miłości Bożej. Zachowują więc sakramentalność zawartego związku małżeńskiego na mocy ich chrztu i udzielania łaski ex opere operato. Osobista wiara zawierających małżeństwo nie konstytuuje bowiem sakramentalności małżeństwa, a jedynie wpływa na 
jego owocność. Także wymagana intencja nupturientów - intencja czynienia tego, co czyni Kościół - która jest minimalnym koniecznym warunkiem do zawarcia związku sakramentalnego, rodzi się z wiary, a brak osobistej wiary może wpłynąć na ważność sakramentu. Toteż ochrzczeni niewierzący, którzy zawierają związek małżeński bez osobistej wiary i intencji czynienia tego, co czyni Kościół, nie zawierają małżeństwa czysto naturalnego. „Dla Kościoła bowiem, między dwojgiem ochrzczonych, nie istnieje małżeństwo naturalne oddzielone od sakramentu, lecz jedynie małżeństwo naturalne podniesione do godności sakramentu" (Międzynarodowa Komisja Teologiczna, Doktryna katolicka o sakramencie matzeństwa, s. 98). Tak Kościół warunkuje życie duchowe tych wszystkich jego członków, wiąże w jedną organiczną całość, spełnia ich i jak najdoskonalej personalizuje tak, że wszyscy chrześcijanie są kimś jednym w Chrystusie Jezusie (por. Ga 3,28).

A zatem ochrzczeni, ale już niewierzący, mogą mieć małżeństwo sakramentalne i nierozerwalne w Kościele katolickim, który też zaradza niedostatkom ich wiary (Ecclesia suplet). Brak żywej i osobistej wiary pozbawia małżeństwo wprawdzie owoców sakramentalnych, ale nie wyklucza - z racji chrztu - z Kościoła, jak też nie wyklucza i z tej racji, że małżeństwo w ogóle jest z woli Bożej (por. Rdz 1,27; 2,24).

Słowa kluczowe: małżeństwo naturalne; małżeństwo chrześcijańskie; małżeństwo ochrzczonych a niewierzących; wiara a sakrament; sakramentalność małżeństwa; wiara i niewiara. 